\title{
Toward making sense of self through emotional experiences in craft-art
}

\author{
Ojala, Milla
}

2018-09

Ojala , M , Karppinen , S \& Syrjäläinen , E 2018 , ' Toward making sense of self through emotional experiences in craft-art ' , Craft Research , vol. 9 , no. 2 , pp. 201-227 . https://doi.org/10.1386/crre.9.2.20

http://hdl.handle.net/10138/311180

https://doi.org/10.1386/crre.9.2.201_1

acceptedVersion

Downloaded from Helda, University of Helsinki institutional repository.

This is an electronic reprint of the original article.

This reprint may differ from the original in pagination and typographic detail.

Please cite the original version. 


\title{
Toward making sense of self through emotional experiences in craft-art
}

\author{
Milla Ojala, Seija Karppinen and Erja Syrjäläinen
}

\begin{abstract}
The goal of this article and the research questions are to present how young craft students make sense of themselves through emotional experiences in craft-art. The study is based on the grounded theory method. The theoretical key concepts, self, emotional experiences and engagement in craft making are chosen based on how they support or resonate with the data and analysis. The data consists of several types of material that was collected in three schools: portfolios, participant observation, ethnographic interviews and students' diaries. The data showed that students' emotions were strongly present in the craft activity. Emotions were related to the students' management of the stages of the craft process, the expectations towards the outcome, the students' holistic bodily and mental feeling during the making and their engagement throughout the entire process. All these elements, reflected against pre-existing theories, indicate that while studying craft-art, the participants were able to make sense of themselves in many ways. The analysis led to the result: Through somatic experience and the emotional ownership of the craft process in which their own interests are materialized in a meaningful product, realisation of students' own potential and a better sense of self becomes possible. This article is a part of the larger study that focuses on students' craft making experiences in the context of Finnish Basic Education in the Arts (BEA).
\end{abstract}

Keywords: Crafts, Craft-art, Emotion, Experience, Self, Engagement, Grounded theory

\section{Introduction}

One afternoon a 17-year-old student of the school of visual arts looks sad and says, 'I can't do anything'. The teacher responds, 'It's not true', but she still does not feel better. Then the student begins to sew a skirt zipper. When it is ready, she smiles as she is very pleased and exclaims, 'Come here to look! How fabulous, just perfect!' The teacher says, 'It really is perfect' and asks, 'How do you feel now?' The student replies, 'Really good! At the end of the lesson, she states, 'At least I can do something'.

This young student studies crafts in the Basic Education in the Arts (BEA) programme in Finland as an after-school activity. The BEA programme is an art education system established by law in 1998 (Act 633/1998) and offers extension in arts education primarily to children and young people who want more practice in arts (National Core Curriculum for Basic Education in the Arts 2002; 2017). The BEA progresses in a goal-oriented manner from one level to the next and provides students with the skills to express themselves and the opportunity to apply for vocational training and education or higher education in this field. Participation is voluntary and the education providers may charge moderate fees. The objectives and core contents are determined in the national core curricula devised by the Finnish National Agency for Education for nine different art forms: music; literary arts; dance; performing arts (circus and theatre) and visual arts (architecture, audiovisual art, visual art and crafts) (Ministry of Education and Culture). 
In the BEA, traditions of crafts making are approached through art, seen as artistic processes and called craft-art (e.g. Karppinen 2005; 2008) as a complement for traditional crafts, which are mainly grounded on model-based processes and evolve from traditional craft methods. Whereas, craft-art is a dialogue between art and crafts, in which art and craft elements are borrowed, adapted and integrated (cf. Pöllänen and Karjalainen 2017) to enhance unique individual expression. Furthermore, in the BEA, craft processes are considered as very personal and intertwined with cultural connections where cognitive, motor and social skills are required and developed (The National Core Curricula for the BEA 2002; 2017; see also Ojala 2013; Karppinen 2005; 2008).

This article is a part of a broader study that focuses on experiences of students in the BEA and their perceptions of themselves as craft makers (Ojala 2013). As the study proceeded to the current stage, the unexpected result was a broad variety of students' emotions from disappointment to happiness, which in some cases they could not even verbalize. These emotional experiences led us to analyse more deeply how emotions are related to craft making and how makers can learn something about themselves through these experiences. In this article the elements and functions of emotional experiences are reflected against such concepts as self, emotional experience and engagement.

Several recent studies have recognised emotions as the essential characteristics of craft and crafts as a meaningful activity for a human being (e.g. Niedderer and Townsend 2014; SeitamaaHakkarainen et al. 2013: 14; Kouhia 2016; Gatt and Karppinen 2014; Karppinen 2013; Groth 2017; Miraglia 2006). Kouhia's (2016) study shows that hobby craft making opens opportunities for selfdiscovery and nurtures emotional sensibility toward the self. Seitamaa-Hakkarainen et al. (2013: 14) show that designing involves rapid movements between positive and negative emotions, such as excitement and anxiety. Miraglia (2006) explored factors that contribute to anxiety in creating art; they may include lack of art knowledge, fear of making mistakes and negative responses from peers or teachers. However, it is not straightforward that negative emotions prevent creation, as they may fade after authentic activity and support in making crafts (Gatt and Karppinen 2014) as it seemed to happen in the example above. Gatt and Karppinen (2014) also noticed that the reflective aspect of the process diary seems to help students to manage their personal emotions and develop a sense of perceived ability toward emotions. Groth (2017) specifies by her studies that emotions are related to haptic and tactile experiences in a creation process, especially in the different decision-making situations (see also Groth 2015; Groth and Mäkelä 2016).

\section{Method and research questions}

This study is based on the grounded theory (GT) method, which was chosen because it is suitable for studying subjects that are complex, processual and dynamic in nature. In the GT method (Corbin and Strauss 2015; Glaser 2001; 2003; 2005), the phenomena are approached without clear presumptions and the intention is to remain receptive during the whole process. According to Corbin and Strauss (2015), several types of data can be mixed and the coding and collecting of data are parallel processes. This kind of theoretical sampling means that analysis guides the research to new directions and the data is collected one step at a time (Corbin and Strauss 2015: 35-137). Consequently, concepts are derived from the data during the analysis, questions about those concepts drive the next round of data collection while research questions develop during the entire process (Corbin and Strauss 2015: 8). The research questions of this part of the study concern the variety of emotional experiences that occurred in the data, how they were related to making a sense of self and the ways that students can make sense of self through their craft-art studies. The research questions are: 
1. What kind of emotional experiences occur in craft-art studies?

2. What is the function of emotional experiences in making sense of self in craft-art studies?

3. In what ways can the students make sense of themselves by studying craft-art in the BEA?

\section{Constructing a conceptual framework}

In the GT study literature review, the pre-existing theories and concepts should not constrain the analysis but they are usually integrated with the findings at the end of the analysis (Corbin and Strauss 2015: 49; Charmaz 2006: 165; Hodkinson 2008). Therefore, in this study the conceptual framework was gradually outlined parallel with the analysis. In the following, some key concepts are investigated and defined, based on how they support and resonate with the data and analysis.

First, the concept of self we understand as a subjective human experience of being someone, also called first-person perspective, which allows representing and integrating multimodal experiences and thoughts into one common framework (Gallagher 2000; Vogeley and Fink 2003). Typically, we experience self as continuous across time and space (Quadflieg and Macrae 2011). The self acts as a unifier that can bundle the outcome of a variety of bodily, cognitive and emotional processes (Ibid.). Bodily self comprises physical self-recognition, bodily self-awareness and the conscious experience of ownership for bodyparts and body as a whole (Bredart and Young 2004; Tsakiris, Schutz-Bosbach and Callagher 2007). The cognitive self involves reflective processes such as introspection, retrieval of personally relevant memories (Maguire 2001: 1441) and activation of self-knowledge (Convay and Pleydell-Pearce 2000; Mclean, Pasupathi and Pals 2007). The emotional self covers mental processes driven by self-based motivational forces such as need to belong (Baumeister and Leary 1995), the need to hold a positive self-image (Mezulis, Abrahamson, Hyde and Hankin 2004) and the tendency to self-enhance (Barrios et al. 2008).

Second, the common concept, human experience, consists of meaningful occurrences that can be created and, consequently, may emerge as instinctive and unintentional (Dewey 1934: 42; Nakamura and Csikszentmihalyi 2014; Mayer 2006; Eisner 2002; Damasio 1999; Goleman 1995). Dewey defines the experience of living beings as interaction with their environment where its active nature occurs in acts and experimentation and its passive nature occurs in experienced reality (Dewey 1916: 147; 1938: 33). The craft-making process is, in proportion, a kind of dialogue between the maker and the material, interaction between the human being and the material world (Illum 2006; Kouhia and Laamanen 2014; cf. Furrer and Skinner 2003). The continuity of experience arises over a longer period by perceiving incidents and through action that directs new experiences (Dewey 1895-1898). Further, craft making is a bodily process that has connections to Shusterman's (2013) definition of somatic experiences. People think and feel with their bodies, especially with the body parts that constitute the brain and nervous system (Shusterman 2013). Eisner (2002) sees that through education, especially art education, people can become architects of their experience and learn to create themselves. Nakamura and Csikszentmihalyi (2014) discuss the human ability to modify experiences through structuring attention. The optimal experience called flow can be reached by any meaningful activity that is challenging enough, leads to a certain goal, gives immediate feedback and continuous enjoyment, requires complex skills, and nourishes intrinsic motivation (Csikszentmihalyi 1990; 1993; 2014). According to Csikszentmihalyi (1990; 1993: 237), every flow experience contributes to the growth of self by developing complexity (see also Csikszentmihalyi and Rathunde 2014).

Third, in this study we discuss emotions as a general concept, although some nuances can be distinguished like feelings and other affective states such as mood and temperament (Gondim and 
Mutti 2011: 197). Therefore, here the concept of emotional experiences includes all the variations of feelings and affective states. Damasio (2000) describes the body as a central scene of emotions where feelings are reflections of changes in bodily conditions and emotional responses give signals to the body and brain (c.f. Shusterman 2013; Custodero 2002). Similarly, a craft maker is involved in a craft process with his or her whole essence and self: body and mind (see Groth 2017) and with varied emotions. In Damasio's (1999: 8, 282) view, different layers of bodily reactions distinguish emotion, feeling of the emotion and the feeling of the feeling of the emotion.

Spendlove (2007) suggests that emotions play an essential role in art and design studies of children through three domains: person, process and product. When developing learners' emotional capacity to engage in a creative process, they can accept emotional ownership of their work (person). The learners experience learning environments that stimulate emotional engagement by being flexible but supportive (process) and take emotional responsibility for the creative outcomes (product) (Spendlove 2007). The concrete product of craft making, an artefact, seems to be one significant motive and orientation for students to engage in their craft-art studies (e.g. Kröger 2016; Rönkkö 2011). Students' perceptions and interpretations, experiences and emotions during the craft process are transformed into concrete qualities of a product or a piece of art that also reflects their experience as makers (Karppinen 2005; Ojala 2013). Many studies indicate that consumers frequently have emotional relationships with products that they have purchased and used (Desmet and Hekkert 2007; Norman 2004; Spillers 2004; Russo et al. 2011; Mayne 2016); they may even state that they love them as Russo et al. (2011) describe. In general, people perceive products via aesthetic impressions, semantic interpretations and symbolic associations that lead to cognitive and affective responses as well as certain behaviour toward the product (Crilly et al. 2004). Desmet and Hekkert (2007) distinguish three components of product experience: aesthetic, meaning and emotion, while, Battarbee and Mattelmäki (2004) classify a meaningful product as one that is a meaningful tool, a meaningful association or a living object that is related to identity, style, taste or linked to memory, emotion or story. These factors also appear to be evident in this study as students described their craft projects and processes.

To gain the optimal craft experience, the maker must be strongly engaged in the activity. This highlights the fourth key concept of this study. Carver and Scheier (2005) note that engagement is related to goals and the accomplishment of a task. Engagement refers to pursuit and persistence to attain something desirable while disengagement is connected to abandonment and letting go (Ibid.). Engagement is often mediated by environmental conditions promoting identity development, selfesteem, initiative or a sense of purpose (Shernoff 2013: 15). Shernoff's (2003; 2010) conceptualization of engagement in learning is rooted in Csikszentmihalyi's $(1990 ; 1993 ; 2014)$ concept of flow, which includes the elements of concentration, effort and interest. Shernoff (2013: 68) describes meaningful engagement as the combination of work-like and play-like activities, in which an individual's effort, utilizing skills and concentration in a chosen activity with personal interest leads to an enjoyable feeling of creative accomplishment.

Conceptual framing displays how craft making seems to be a complex phenomenon including several theoretical and conceptual paths to follow. After presenting the data analysis and its findings, we will revisit the key concepts and discuss how they reflect the data. 


\section{Data and analysis}

Several types of data were collected in three Basic Education in the Arts schools in the cities of Hämeenlinna, Valkeakoski and Lahti in 2014 and 2015. Students were 14-18-year-old craft-art students who studied weekly in an after-school activity. The main data consists of student's ethnographic interviews $(\mathrm{N}=11)$ during hands-on lessons (cf. Gobo 2008; Rastas 2010). Additional data consists of written portfolios $(\mathrm{N}=10)$ of students' final projects, students' diaries $(\mathrm{N}=5)$, participant observations (16h) and recorded students' conversations.

The portfolios formed a basis for further data collection and interviews. The interviews proved to be the most rich and informative. The researcher participated twice in four-hour sessions in both Valkeakoski and Lahti. The interviews (short discussions) were recorded. The discussions among the researcher, students $(\mathrm{N}=9)$ and teachers $(\mathrm{N}=2)$ concerned current craft projects and memories of past projects. The teachers' participation in the discussion between the researcher and the students opened a new view to the conversation.

Figure 1: In Lahti, students designed and manufactured their own clothing line. Photo by Milla Ojala

Figure 2: In Valkeakoski, students implemented their individual projects in wood and fabric. Photo by Milla Ojala

The data was selected by discretionary sampling (e.g. Tuomi and Sarajärvi 2002: 88-89; Cohen et al. 2000: 102) according to its relevance. The study follows the common ethical principles and anonymity in all stages; research consent was requested from the participants and their parents (see Corbin and Strauss 2015: 44; Gomm 2004).

The data was reviewed several times, transcribed, coded and analysed gradually as a parallel process with data collecting. Continuing analysis helps the researcher focus the new data gathering on essential matters, prepare precise questions and verify earlier results (Corbin and Strauss 2015: 136; Hodkinson 2008). The informative and essential parts were transcribed precisely (42 pages/13,400 words). All the examples presented in the article are identified with letter and number codes: $\mathrm{S}=$ =student; $\mathrm{T}=$ =teacher; $\mathrm{R}=$ =researcher; $\mathrm{V}=$ Valkeakoski; $\mathrm{L}=$ Lahti; $\mathrm{H}=$ Hämeenlinna; $\mathrm{I}=$ Interview; $\mathrm{P}=$ Portfolio and $\mathrm{D}=$ Diary.

The analytic strategies used in the study were asking questions, comparing constantly one piece of datum against another and naming incidents in the data (Corbin and Strauss 2015: 90-93). Important analytic tools were writing memos and drawing diagrams to discuss the data to discover categories, concepts and relationships (Ibid: 106-107). When the analysis goes further, concepts must be woven together in conceptual terms, which concerns also explanations and meanings that craft makers give to their action and possible consequences of their action (Ibid: 157-59). Analysing process in the data also shows movement, patterns and variations under certain conditions (Ibid: 177-178). 


\section{Results}

\section{Emotional experiences in craft-art studies}

Expressions of emotions often occurred in the data, especially in recorded conversations; however, students' emotional reactions through non-verbal communication were also observed. In the first stage of analysis, which is called open coding in GT, these incidents were coded to a category that was labeled emotional experiences. Figure 3 illustrates the variety of emotional experiences that occurred in the data. They are divided to five main groups: joy of accomplishment; fear of failure; disappointment; enthusiasm and relaxation. Each group can include both positive and negative emotions.

\section{Figure 3: Emotional experiences during craft-art process}

Joy of accomplishment was related to the best highlights of the craft making process; for example, one student (IVS3) wrote, 'If I succeed I have a feeling that I wanna dance or something like that'. Loving, liking, attachment and contentment were feelings caused by seeing the result, trying some technique or facing some incident in the process.

Fear of failure was experienced in critical situations when something was expected to be difficult to perform or the maker was unsure what he or she was supposed to do. As Miraglia (2006) states, anxiety in creating art may include a fear of making mistakes or receiving a negative response from a teacher. A student explained:

These kinds of activities are difficult; they scare me a lot and then I am stressed out about it and wonder if it succeeds. Sometimes I am afraid to make it by myself and I ask for help all the time, just to make sure, even if I knew how and if I could do it. Still I just have to ask and be sure that nothing happens. (IVS4)

Uncertainty, panic, fright and stress were described to appear because of fear of failure. Groth et al. (2013) found that emotion helped the craft maker to pay the right amount of attention when managing critical moments. Confidence was the opposite feeling that was experienced when there was no fear of failure and the plan was clear. For instance, a student (IVS5) said about designing a dress: 'Yes, I had an inspiration. Now I know exactly what I am going to do!' Whereas, disappointment was experienced when something went wrong or the result did not correspond to the maker's expectations.

R: $\quad$ Mmm. If you see something that doesn't please you, how do you feel?

VS1: Terrible. I don't like it.

R: What do you think then?

VS1: Well, nothing really. I just finish it anyway and I think that I don't like this and then usually I throw it away somewhere.

Irritation, annoyance and anger were the different shades of disappointment, for example, it could be annoying when something took a lot of time to make or material ability was not high enough, as a student's (IVS1) comment indicates: 'This plastic irritates me because it moves like that [slides]'. 
Enthusiasm was related to the maker's motivation towards the making process; as one of the participants (ILS8) said, 'I have a feeling I want to work. This drives me on'. Lack of enthusiasm seems here to lead to boredom.

Moreover, relaxation was connected to bodily feelings that making craft-art elicits. Craft making could feel unpleasant or tiring and be described as bodily discomfort. Bodily comfort includes relaxation and other positive bodily experiences that were not always easy to describe.

R: How does it feel to paint?

VS4: I can't explain it. It just feels relaxing and nice. The feeling it causes cannot be explained. You have to feel it yourself.

\section{Emotional experiences in making sense of self in the craft-art studies}

In the stage of the axial coding, the aim was to reach a more abstract level by indicating relationships and structures of the phenomena (Corbin and Strauss 2015: 130; Charmaz 2006: 6061). By comparing, asking questions, going back and forth between data and analysis (Corbin and Strauss 2015: 239-241), three elements in which the emotional experiences were related to: management of the process, maker's own aesthetics and maker's presence were distinguished.

\section{Management of the process}

Emotions were related to managing the craft process. The maker steers his or her process of making through several phases. Along the way, the maker faces good moments as well as difficulties (cf. Seitamaa-Hakkarainen et al. 2013). One participant (PHS2) described it: 'Sometimes I felt joy and a feeling of success, sometimes irritation because something didn't succeed or go just as I had planned'. As Dewey (1934: 2) expresses, every moment of the process has its own emotional tone; one cannot separate emotion from action. A student (PHS7) wrote in her portfolio: 'The sewing was the most motivating step in making a dress. It was wonderful to notice that the work proceeds. Every step motivates me in a different way'.

Emotion seemed to have a certain energy that directed the process (see Groth et al. 2015); this was the first property that was found in the axial coding: The energy of emotion. It can vary in the dimension from obstructive to conducive (see examples in the previous chapter). Conducive emotions support the motivation of the maker and direct the process forward, while obstructive emotions do the opposite. They can weaken the motivation and retard the process; in some cases, they can even stop it completely (e.g. Gatt and Karppinen 2014).

The emotions can also be seen as encouraging or discouraging. This property is called the dynamics of emotion. Encouraging emotions help to create a positive image of the maker's skills; they encourage him or her to become more skilful in craft making and maintain the motivation. This can be seen as parallel with Czikszentmihalyi's $(1990 ; 1993 ; 2014)$ flow experience. Discouraging emotions decrease confidence, enthusiasm and interest in doing quality work. A student (DHS2) who rarely expressed her feelings aloud wrote in her diary: 'When an unexpected problem arises, I think first that fxxk, I never get my work done, but then I gather myself and ask for help with my problem'. Another student (ILS7) described her dressmaking project that had lasted a whole year. At some point, she felt hopeless with the dress because it looked so ugly on her. Finally, when the dress was finished she described a feeling of happiness: 'I put it on, I had tears of happiness on my cheeks; it was so nice'. It seemed that the emotions have certain functions in managing the craft 
process. The energy of emotion appears concretely in the way that the craft process proceeds and the dynamics of emotion explicate how the making supports the maker and either increases or decreases belief in his or her abilities.

\section{Maker's own aesthetics}

The emotions were related to the maker's own aesthetics. The students constantly seemed to evaluate the aesthetic result of their making (cf. Desmet and Hekkert 2007). They were very aware of what was as desirable result and what was not; the typical expression found in the data was 'It is my style' or 'It is something I like'. The products seemed to be full of meaningful associations (see, Battarbee and Mattelmaki 2004) in the discourse between the makers and their environment (Buckley and Saarni 2006). A student (PHS1) wrote in her portfolio: 'I made a final project that couldn't be more look like me; both the bag and the dress show my personal style and taste so they clearly include something of my own'.

Gradually seeing the result of the process could cause disappointment, as well as feelings of joy and contentment. The emotional state varied from appreciation of the artefact to negative emotions such as irritation or anger, which at worst led to rejection of the work. As one student (IVS1) said: 'When I want it to be perfect, if I see there is something wrong with it, I don't like it and I don't want to finish it'.

Because of craft making, the material is transformed to a concrete artefact. A maker's different abilities can be seen as the qualities of the artefact, as the artefact mirrors the trace of the maker's hands and actions. We agree with Groth and Mäkelä (2016) who claim that this probably is a very significant element in building the maker's self-esteem or self-perception. For example, the students in Lahti (ILS678) said that their skills and understanding had developed; they also mentioned that their ability to undertake challenging projects had increased. They felt that projects at which they have aesthetically succeeded have made them more confident as craft makers.

\section{Maker's presence}

The category in which the emotions were related to the maker him or herself, was labeled the maker's presence. Presence refers to a subjective human experience of being someone (self), which includes bodily, cognitive and emotional elements (Quadflieg and Macrae 2011). Groth (2013) asserts that when makers touch a material, they simultaneously feel themselves and become aware of 'being'. In this sense, making can be considered a way of being is in contact with oneself.

In the data, these experiences were described in situations where the participants observed their bodily sensations or their mental feeling; neither was easy to verbalize. In the data, the bodily sensation varied from unpleasant to pleasant during the actual making. For example, a student may feel relaxed while painting, but then be tired by smoothing the artefact with sandpaper. Moreover, a student (ILS6) described sewing by hand as 'meditative' making.

Emotions concerning oneself during the making process are here called the mental feeling. This could include perceptions of their own motivation or ability to concentrate at a certain moment. Typically, the students felt profoundly positive feelings about themselves when they had succeeded at some challenging stage of their project or they had successfully completed their work. This phenomenon was labeled the sense of competence. For example, a student (PHS8) wrote in her portfolio: 'Anyway, I grew wiser when making my final project and making it made me more skilled, stronger and more confident in my own abilities'.

A craft process does not always proceed as planned. The opposite of a good feeling was called the sense of incompetence. In many ways, the disappointment in craft making can be an unpleasant 
experience as can be seen in a student's (IVS1) comment about her unsuccessful product: 'Then I just look at it and I think that, I can't help that it is the way it is and I just have to live with it'. The teacher (IVT1) described a student who had rejected her work several times because the outcome did not correspond to her original vision. The teacher interpreted the situation that it was the student's way of avoiding the disappointment at not finishing her work. This is also a good example of the dynamics of emotion in the craft process when craft makers have momentary difficulties believing in themselves and their potential.

Figure 4: Three subcategories of emotional experiences: properties and dimensions according to GT procedures of axial coding (Corbin and Strauss 2015: 61; Saldana 2013: 218)

\section{Three types of engagement in craft-art}

The data consists of participants' descriptions of different aims and aspirations they have in studying craft-art. These enlighten the basis of their motivation and explain the meanings of craft making to them. This category was called engagement. Three types of engagement were found: artefact-centred, maker-centred and process-centred (cf. Spendlove 2007). The engagement function is a personal approach and driving force of craft making (see Newman 1986; Furrer and Skinner 2003). The most common type of engagement was the artefact-centred, in which the students' main purpose was to make products for themselves. In this case, students attached great importance to the aesthetics, function and quality of the product. In some cases, engagement was related to the students' need to express themselves; one student (IVS2) explained: 'Here I am able to create by myself and express myself'. The freedom to make original artefacts was valuable to them; this was called the maker-centred engagement. The third type of engagement appeared in experimenting with different materials so that the process of learning was valued more than the outcome of the process or there was no outcome. One teacher (IVT1) described a student who only wanted to practise: 'For one year she made garments on a mannequin. She didn't make them for herself'. This type of process was called the process-centred engagement.

In conclusion, the engagement was not a stable state of mind but varied in different situations or in different projects. One of the students (ILS7) discussed her ultimate motivation for craft making: 'I like when I have an idea. I love to see it develop, though the result is not the main object but realizing my own potential is'.

\section{BEA students can make sense of themselves by studying craft-art}

Figure 5 illustrates the elements of making sense of the self in craft-art. Through the three different types of engagement the students described the basis of their craft making. They could make such direct conclusions about themselves based on their experiences of craft making as one said (IVS1): 'Well, probably because I lose my temper easily, the work starts to irritate me and I change it'. In addition, the making sense of self is connected to the three areas of emotional experiences. The subcategory management of the process consists of a variety of incidents in which the participants express something about their personal methods during the craft process. They can recognise their way of working, way of thinking and skills or the evolution of changes in these areas. A student (PHS4) describes in her portfolio: 'I learned a lot in making my final project. Maybe, I learned most what kind of a craft maker I am and what kinds of working methods suit me.' Typically, perceptions about the personal methods were related to emotional experiences when the participants 
experienced their making as somehow challenging. They also compared themselves to other members of the group, for instance how fast, efficient, confident or skillful they were; one student (ILS6) commented: 'Well, I won't succeed at making it as nicely as Laura. I can't make precise surgeon's stitches as Laura can; I have a looser style'.

The participants also recognized their personal ways of thinking. Some of them described themselves as rather unconditional in implementing their design and others were more flexible and let the process carry them along. When asked about how she anticipated the actions in the making, one student (VS2) said, 'No, I cannot know what is to come but I can be flexible with the plan and change it'. The participants observed their skills and described developing technical skills as well as thinking skills, managing the process or improving their methods: 'I am such a perfectionist. I have learned to control it. I can draw one line for a couple of hours ... I have tried to learn not to do this, that it doesn't have to be perfect' (ILS7).

Many of the participants could identify their skills, strengths and weaknesses. One explained that she had found 'the limits of her skills' when the assignment was challenging and she had to use all her capacity. The experience was very rewarding. This incident in the data verifies Csikszentmihalyi's $(1990 ; 1993)$ description about the flow experience.

The student (LS7) explained, 'If you do some quite basic tasks but near the limits of your skills, you can make the garments that you are really proud of. Approaching the limits of your skills makes it a little bit more fun'.

In the subcategory of maker's presence, the making sense of self occurred through bodily sensations and mental feeling. The makers could observe how their alertness, stress or fatigue seemed to affect their work activity. Sometimes they said that craft making felt so good that it made them feel good about themselves as well. Groth (2017: 60) noted the importance of bodily experiences in craft making not only to gain different abilities but also to build a craft maker as a practitioner.

Figure 5: The categories and subcategories found in the analysis

In conclusion, according to the data, making sense of self was discovered through participants' personal engagement in craft studies, their own ways of managing craft processes, their thoughts about aesthetics of artefacts that they had made themselves and their emotional experiences of their presence in the act of making.

\section{Discussion}

In the following, we combine the categories discovered together with conceptual framework that were constructed to reflect, explain and support the results (see Figure 6). The making sense of self in craft-art begins with somatic experience by the touch of the material and the use of tools. That, including the variety of emotional experiences and meaningful engagement in the craft activity, can lead to a transformed knowledge of self. 
Figure 6: The relation between categories found in the analysis and the conceptual framework of the study

The students seemed to have very individual ways of engaging in craft-art studies, focusing on their own interests and expending effort and concentration (cf. Shernoff 2010) on their craft projects. This gives the craft activity a personal meaning. The experienced meaningful engagement can be described in Shernoff's words (2013) as a combination of 'play-like' and 'work-like'. These elements were emphasised in different ways in the three types of engagement discovered in this study. For example, in artefact-centred engagement the craft maker pursued, in the first instance, skillful outcome, while process- and maker-centred engagement involved a more playful and experimental attitude.

The characteristics of flow, such as: a clear goal, immediate feedback and a balance between challenges and skills (Csikszentmihalyi 1990; 1993; 2014), seem to explain the emotional experiences. In the flow experience, personal skills must be well suited to the given challenges; craft makers experience a variety of emotions when they alternate between anxiety and boredom when developing skills in order to maintain flow (Csikszentmihalyi 1990; 1993; 2014, see Shernoff 2013). One of the main discoveries of the analysis (in the subcategory of management of the process) was that emotional experiences seemed to have a certain energy and dynamic in the craft process, which either advance or obstruct the process and encourage or discourage the craft maker. This finding confirms Csikszentmihalyi's (1988; 1990; 1993) notions of flow experience as one form of energy and Dewey's (1934: 42) descriptions of emotion as the moving and cementing force of experience.

The subcategory of maker's own aesthetics describes the continuous evaluation of the outcome. This shows how the interaction with the material world in the craft process is fraught with meaning (Groth 2017; Illum 2006; Kouhia and Laamanen 2014; Dewey 1934; Eisner 2002) and the materialistic aims are also present in the activity of craft-art. According to Desmet (2002), the emotions are more likely elicited by products, both pleasant and unpleasant; reactions can be inspiration, surprise, satisfaction, boredom, disappointment and irritation. The same emotional reactions were found in the data and they occurred during the making process. Desmet and Hekkert (2007) suggest that the user-product interaction is an emotional experience including aesthetic experience and experience of meaning. When a consumer obtains the first aesthetic impression of a product, he or she weighs the aesthetic ingredients: objective and subjective information (Crilly et al. 2004). When a craft maker evaluates a self-made object, according to the data it seemed that his or her attention was often drawn to mistakes, which was likely to trigger emotional experiences toward the outcome. On the other hand, there were descriptions in the data about contentment, the practical qualities of the artefact, which is a part of semantic interpretations given to products (Ibid.). Many students valued the personal unique appearance of a self-designed object that contained a symbolic association that allowed them to communicate their identity through products (Ibid.). Our interpretation is that the outcome of the craft process is a realisation of the maker's visual thoughts and aesthetic appreciation, as well as a concrete demonstration of the maker's skills. Consequently, emotional experiences are related to seeing a gradually completed result: a meaningful product.

The physical interaction between one's body and the material and tools, the somatic experience, is the essential basis of the craft experience, because by touching the material the maker also feels and becomes aware of being (Groth 2017; Shusterman 2013). The subcategory of maker's presence refers to craft making as a holistic experience where the continuity of experience (Dewey 1895- 
1898) includes bodily sensations as well as mental feeling. Damasio's (1999) idea of the body as the central site of emotions leads to the thought that it is natural to be also emotionally engaged in a craft project; the experience is meaningful and rewarding in a holistic manner through both the body and the mind.

Csikszentmihalyi $(1990 ; 1993 ; 2014)$ states that during a flow experience, a person can feel a loss of awareness of oneself, transcendence of ego boundaries, a sense of growth and a feeling of being part of some greater entity (see also, Nakamura and Csikszentmihalyi 2014). In flow activity attention is not focused on oneself, although a person can be very aware of one's body movements, thoughts and feelings (Ibid.).

Csikszentmihalyi $(1990 ; 1993)$ outlines that flow helps to build mental integration, because in deep concentration it is easier to maintain inner coherence (see also Csikszentmihalyi and Rathunde 2014). Furthermore, Eisner (2002: 19) presents that artistic work affects awareness of oneself in several ways by refining the senses so that the ability to experience the world is made more complex and subtle by generating thinking and promoting the use imaginative capacities. In the analysis, the holistic experience of self was called mental feeling. When the psychic energy was committed totally to individual work, the experience was complete and harmonious. Overcoming the challenges made the participants feel more skilled and competent. Groth and Mäkelä (2016) found that manipulating materials in craft activity were related to the craft makers' self-esteem and image of themselves as practitioners. Consequently, the balance between skills and challenges, the harmony of bodily and mental feeling can create the sense of competence.

As not all the craft processes succeeded in all cases, the most difficult feelings, the opposite to the sense of competence, were called the sense of incompetence, yet, these emotional experiences with a negative tone appear to also have an important function in making a sense of self. Groth et al. (2013) point out that the process is always a struggle with the material, which has its own will; because of this interaction, the artefact embodies both the material and the self. According to Spendlove (2007), uncertainty is actually a prerequisite for creativity in art and design education and the pedagogy should enable development of emotional ownership through meaningful engagement in the process so that students are also able to manage discouraging and obstructive emotional experiences. In the BEA system, the learning environment is fairly open; the curriculum permits a teacher the space to create learning tasks in which genuine problem solving is a significant part of the pedagogy (The National Core Curricula for the BEA 2002). Consequently, the data indicated that these situations also created an opportunity for students to reflect on themselves, to make sense of their reactions and draw conclusions about their feelings and responses during the act of creating.

\section{Conclusions}

The goal of this article was to present the complex process of young craft makers making sense of themselves through emotional experiences in craft-art. The data showed that the emotions were strongly present in the craft-art activity. The analysis led to the result that through somatic experience and the emotional ownership of the craft process, in which student's personal interests are materialized in a meaningful product, a realisation of one's own potential and in the best cases better sense of self can be achieved.

The study conceptualised the intrinsic characteristics of craft as noted by Niedderer and Townsend (2014) who said: '[it has an] ability to capture and invoke intimacy and emotion'. Charmaz (2006: 
182-183) presents four criteria for the Grounded Theory studies: credibility, originality, resonance and usefulness. In terms of credibility, this study can be convincing because, although the number of the participants was not high, the data proved to be rich. The ethnographic interviews enabled the researcher to access the very moment and place when emotional experiences occurred. The categories cover a wide range of empirical incidents and the process of coding gave weight to the phenomena that were described in original and fresh terms.

The study offers insight on craft research concerning craft makers' experiences in the Basic Education in the Arts in Finland. However, the results may well be useful in varied fields of art and craft education. At least the study raises more questions about what exactly are 'the mechanisms' of creative, experiential and relatively free learning processes, such as craft-art processes in the BEA and how do they develop a human being. However, the learning environment and craft pedagogy in the BEA should be further examined to determine how they enable students to make a better sense of self. 


\section{References}

Barrios, V., Kwan, V.S.Y, Ganis, G., Gorman, J., Romanowski, J. and Keenan, J.P. (2008), 'Elucidating the neural correlates of egoistic and moralistic self-enhancement', Consciousness and Cognition, 17:2, pp. 451-456.

Battarbee, K. and Mattelmäki, T. (2004), 'Meaningful product relationships', in D. Macdonagh, P. Hekkert, J. van Erp and D. Gyi, (Eds.), Design and Emotion: the Experience of Everyday Things, London: Taylor \& Francis, pp. 391-399.

Baumeister, R.F. and Leary, M.R. (1995), 'The need to belong: Desire for interpersonal attachment as a fundamental human motivation', Psychological Bulletin, 117:3, pp. 497-529.

Brédart, S. and Young, A.W. (2004), 'Self-recognition in everyday life', Cognitive Neuropsychiatry, 9:3, pp. 183-197.

Buckley, M. and Saarni, C. (2006), 'Skills of Emotional Competence: Developmental Implications', in J. Ciarrochi, J. Forgas and J. Mayer (Eds.), Emotional Intelligence in Everyday Life, (2nd Ed), New York: Psychology Press, pp. 51-76.

Carver, C.S. and Scheier M.F. (2005), 'Engagement, Disengagement, Coping and Catastrophe', in A.J. Elliot and C.S. Dweck, (eds.), Handbook of Competence and Motivation, New York: Guilford press, pp. 527-547.

Charmaz, C. (2006), Constructing Grounded Theory: A Practical Guide Through Qualitative Analysis, London: Sage.

Cohen, L., Manion, L. and Morrison, K. (2000), Research methods in education, (5th ed.), London: Routledge/Falmer.

Convay, M. and Pleydell-Pearce, C.W. (2000), 'The construction of autobiographical memories in the self-memory system', Psychological Review, 107:2, pp. 261-288.

Corbin, J. \& Strauss, A. (2015), Basics of Qualitative Research: Techniques and Procedures for Developing Grounded Theory, (4th ed.), Thousand Oaks: Sage.

Crilly, N., Moultrie, J. \& Clarkson, P.J. (2004), 'Seeing things: Consumer response to the visual domain in product design', Design studies, 25:6, pp. $547-577$.

Crozier, W.R. (2000), 'Shyness and relationships: continuity and change', in W.R. Crozier (Ed.), Shyness: Development, Consolidation, and Change, London: Routledge, p. 71.

Csikszentmihalyi, M. (1988), The flow experience and human psychology, in I.S. Csikszentmihalyi and M. Csikszentmihalyi, Optimal experience: Psychological studies of flow in consciousness, Cambridge: Cambridge University Press. pp. 15-35.

Csikszentmihalyi, M. (1990), Flow: The Psychology of Optimal Experience, New York: HarperCollins.

(1993), The Evolving Self, New York: HarperCollins.

(2014), 'Toward a Psychology of Optimal Experience', in M. Csikszentmihalyi, (2014), 'Flow and the foundations of positive psychology: The collected works of Mihaly Csikszentmihalyi', Berlin: Springer. pp. 209-226.

https://link.springer.com/book/10.1007/978-94-017-9088-8/page/1 Accessed 9 June 2017.

Csikszentmihalyi, M. and Rathunde, K. (2014), 'The Development of the Person: An Experiental Perspective on the Ontogenesis of Psychological Complexity', in M. Csikszentmihalyi, Applications of flow in human development and education: The collected works of Mihaly Csikszentmihalyi. Dordrecht: Springer. pp. 7-79. 10.1007/978-94-017-9094-9_2 Accessed 9 June 2017.

Custodero, L. (2002), 'Seeking Challenge, Finding Skills: Flow Experience and Music Education'. Arts Education Policy Review, 103:3, pp. 3-9. 
Damasio, A. (1999), The feeling of what happens: Body and emotion in the making consciousness, New York: Harcourt.

Desmet, P. (2002), Designing Emotions, Ph.D. thesis, Delft, Netherlands

Desmet, P. and Hekkert, P. (2007), 'Framework of Product Experience', International Journal of Design, 1:1, pp. 57-66.

Dewey, J. (1895-1898), 'Early essays: The Reflex Arc Concept in Psychology', in The Early works of John Dewey, 1882-1898, 5: 1895-1898, Essays, The Collected Works of John Dewey, 1882-1953, (Electronic Edition), Intelex, Past Masters, pp. 97-110.

http://pm.nlx.com.libproxy.helsinki.fi/xtf/view?docId=dewey_ii/dewey_ii.05.xml;chunk.i $\mathrm{d}=$ div.ew.5.20;toc.id=div.ew.5.20;jumped2page=yes;brand=default;query=97\#pb-97 Accessed 10 September 2015.

(1916), 'Experience and thinking: Democracy and Education: An introduction to the Philosophy of Education', in The Middle Works of John Dewey, 1899-1924, 9: 1916, The Collected Works of John Dewey, 1882-1953, (Electronic Edition), Intelex, Past Masters.

http://pm.nlx.com.libproxy.helsinki.fi/xtf/view?docId=dewey_ii/dewey_ii.14.xml;chunk.i d=div.mw.9.23;toc.id=div.mw.9.23;jumped2page=yes;brand=default;query=147\#pb-147 Accessed 10 September 2015.

(1920), 'Changing Conceptions of Philosophy: Reconstruction in Philosophy', The Middle Works of John Dewey, 1899-1924, 12: 1920, Essays, The Collected Works of John Dewey, 1882-1953, Electronic Edition, Intelex, Past Masters, pp. 81-95. http://pm.nlx.com.libproxy.helsinki.fi/xtf/view?docId=dewey_ii/dewey_ii.17.xml;chunk.i $\mathrm{d}=$ div.mw.12.25;toc.id=div.mw.12.25;jumped 2 page $=$ yes; brand $=$ default;query $=82 \# p b-82$ Accessed 12 September 2015

(1934), Art as Experience, New York: Perigee Books.

(1938), 'The Existential Matrix of Inquiry: Biological. Logic: The Theory of Inquiry', in The Later Works of John Dewey, 1925-1953, 12: 1938, The Collected Works of John Dewey, 1882-1953, (Electronic Edition), Intelex, Past Masters, pp. 31-48.

http://pm.nlx.com.libproxy.helsinki.fi/xtf/view?docId=dewey_ii/dewey_ii.32.xml;chunk.i $\mathrm{d}=$ div.lw.12.10;toc.id=div.lw.12.10;jumped2page=yes;brand=default;query=33\#pb-33 Accessed 12 September 2015.

Eisner, E. (2002), The Arts and the Creation of Mind, London: Yale University press.

Furrer, C. and Skinner, E. (2003), 'Sense of relatedness as a factor in children's academic engagement and performance', Journal of Educational Psychology, 95:1, pp. 148-162.

Gallagher, I. (2000), 'Philosophical conceptions of the self: Implications for cognitive science', Trends in Cognitive Sciences, 4:1, pp. 14-21.

Gatt, I. and Karppinen, S. (2014), 'An Inquiry into Primary Student Teachers' Confidence, Feelings and Attitudes towards Teaching Arts and Crafts in Finland and Malta during Initial Teacher Training', The International Journal of Art \& Design Education, 33:1, pp. 7587.

Glaser, B. and Strauss, A. (1967), The Discovery of Grounded Theory: Strategies for qualitative reseach, New York: Aldine Publishing Company.

Glaser, B. G. (2001), The Grounded Theory Perspective: Conceptualization Contrasted with Descripition. Mill Valley: Sosiology Press.

(2003), Grounded Theory Perspective 2: Description's Remodeling of Grounded Theory Methodology, Mill Valley: Sociology Press.

(2005), Grounded Theory Perspective 3: Theoretical coding, Mill Valley: Sociology Press.

Gobo, G. (2008), Doing ethnography, Sage, Research methods,

http://srmo.sagepub.com.libproxy.helsinki.fi/view/doing-ethnography/SAGE.xml.

Accessed 26 October 2016. 
Goleman, D. (1995), Emotional Intelligence. New York: Bantam Books.

Gomm, R. (2004), Social Research Methodology: A critical introduction, New York: Palgrave Macmillan.

Gondim, S.M.G. and Mutti, C. (2011), 'Affections in learning situations: a study of an entrepreneurship skills development course', Journal of Workplace Learning, 23:3, pp. $195-208$.

Groth, C. (2017), 'Making Sense through Hands: Design and Craft Practice Analysed as Craft Practice', Ph.D. thesis, Aalto University, School of Arts.

(2015), 'Emotions in risk-assessment and decision- making processes during craft practice', Journal of Research Practice, AU Press, Canada, pp. 11-2.

Groth, C. and Mäkelä, M. (2016), 'The knowing body in material exploration', Studies in Material Thinking, AUT University, Australia, 14, article 02.

Groth, C., Mäkelä, M. and Seitamaa-Hakkarainen, P. (2015), 'Tactile Augmentation: A multimethod for capturing experiential knowledge', Craft Research, Intellect, 6:1, pp. 57-81.

(2013), Making Sense-what can we learn from experts of tactile knowledge? FORMakademisk Journal, 6:2, 1-12.

Illum, B. (2006), 'Learning in practice-practical wisdom—the dialog of the process', Journal of Research in Teacher Education, 2-3:2006, pp. 107-127.

Hodkinson, P. (2008), 'Grounded Theory and Inductive Research', in N. Gilbert, (Ed.), Researching Social Life, (3rd Edition), London: Sage, pp. 80-100.

Karppinen, S. (2005), ' Mitä taide tekee käsityöstä?” Käsityötaiteen perusopetuksen käsitteellinen analyysi', Ph. D thesis, University of Helsinki, Faculty of Education, Studies 263.

(2008), 'Craft-art as Basis for Human Activity', International Journal of Art \& Design Education, Oxford: Blackwell, 27:1, pp. 83-90.

(2013), 'Primary student teachers' perceptions of their prior experiences with craft-making in the light of Hannah Arendt's human condition', Techne series A, 20:2, pp. 2-16.

Kouhia, A. (2016), 'Unraveling the meanings of textile hobby crafts', Ph.D. thesis, University of Helsinki, Faculty of Behavioural Sciences, Department of Teacher Education.

Kouhia, A. and Laamanen, T-K. (2014), 'Mitä muuta kuin materiaa? Otteita käsityön materiaalisuudesta ja immateriaalisuudesta', in S. Karppinen, A. Kouhia and E. Syrjäläinen, (Eds.), Kättä pidempää: Otteita käsityön tutkimuksesta ja käsitteellistämisestä, University of Helsinki, Faculty of Behavioral Sciences, Department of Teacher Education, pp. 11-12.

Kröger, T. (2016), 'Diverse orientations in craft education: Student teachers' conceptions and perceptions', Techne series A. Research in Sloyd Education and Crafts Science, 23:1, 114.

Lipka, R.P. and Brinthaupt, T.M. (1992), 'Introduction', in R.P. Lipka and T.M. Brinthaupt, Selfperspectives Across the Life Span, New York: SUNY Press, p. 3.

Maguire, E.A. (2001), 'Neuroimaging studies of autobiographical event memory', Philosophical Transactions of the Royal Society of London B, 356:1413, pp. 1441-1451.

Mayer, J. (2006), 'A New Field Guide to Emotional Intelligence', in J. Ciarrochi, J. Forgas and J. Mayer, (Eds.), Emotional Intelligence in Everyday Life, (2nd Ed.), New York: Psychology Press, 3-26.

Mayne, A. (2016), 'Feeling lonely, feeling connected: Amateur knit and crochet makers online', Graft Research, 7:1, pp. 11-29.

Mclean, K.C., Pasupathi, M. and Pals, J.L. (2007), 'Selves creating stories creating selves: A process model of self-development', Personality and Social Psychology Review, 11:3, pp. $262-278$. 
Mezulis, A.H., Abrahamson, L.Y., Hyde, J.S. and Hankin, B.L. (2004), 'Is There a Universal Positivity Bias in Attributions? A Meta-Analytic Review of Individual, Developmental, and Cultural Differences in the Self-Serving Attributional Bias', Psychological Bulletin, 130:5, pp. 711-747.

Ministry of Education and Culture. http://minedu.fi/en/basic-education-in-arts. Accessed 7 December 2017.

Miraglia, J.L. (2006), 'Conceptions of art: a case study of elementary teachers, a principal and an art teacher', Ph.D. thesis, University of Massachusetts, Amherst, Dissertations Abstracts International, 138, (UMI No. 3242105).

Nakamura J. and Csikszentmihalyi, M. (2014), 'The Concept of Flow', in M. Csikszentmihalyi, Flow and the foundations of positive psychology: The collected works of Mihaly Csikszentmihalyi, Berlin: Springer, pp. 239-263.

https://link.springer.com/book/10.1007/978-94-017-9088-8/page/1. Accessed 9 June 2017.

Niedderer, K. and Townsend, K. (2014), 'Designing Craft Research: Joining Emotion and Knowledge', The Design Journal, 17:4, 624-647.

Norman, D.A. (2004), 'Emotional Design: Why We Love (or Hate) Everyday Things', New York: Basic Books.

Ojala, M. (2013), 'Constructing knowledge through perceptual processes in making craft-art, in M. Johansson and M. Porko-Hudd, (Eds.), Making, Materiality and Knowledge. Techne series A, Research in Sloyd Education and Crafts, pp. 62-75.

Pöllänen, S. and Karjalainen, K. (2017), 'Dialogue between art and craft: Textile materials and techniques in contemporary art', International Journal of Education \& the Arts, 18:1, pp. $1-17$.

Quadflieg, S. and Macrae, C.N (2011), 'Note to Self', in J. Decety and J.T. Cacioppo, (Eds.), The Oxford Handbook of Social Neuroscience, New York: Oxford University Press, pp. 325334.

Rastas, A. (2010), 'Haastatteluaineistojen monet tehtävät etnografisessa tutkimuksessa', in J. Ruusuvuori, P. Nikander \& M. Hyvärinen, (Eds.), Haastattelun analyysi, Tampere: Vastapaino, pp. 64-89.

Russo, B., Boess, S. and Hekkert, P. (2011), "' What's Love Got to Do with It?" The Experience of Love in Person-Product Relationships', Design Journal, 14:1, pp. 8-27.

Rönkkö, M. (2011), Käsityön monet merkitykset. Opettajankoulutuksen opiskelijoiden käsityölle antamat merkitykset ja niiden huomioon ottaminen käsityön opetuksessa, Series C, Part 317, University of Turku.

Saldana, J. 2013, The Coding Manual for Qualitative Researchers, Second edition, London: Sage.

Seitamaa-Hakkarainen, P., Laamanen, T.-K., Viitala, J \& Mäkelä, M. (2013), Materiality and Emotions in Making', in M. Johansson and M. Porko-Hudd, (Eds.), Making, Materiality and Knowledge, Techne series A. Research in Sloyd Education and Crafts Science, 20(3), pp. 5-19. https://journals.hioa.no/index.php/techneA/article/view/702. Accessed 7 January 2014.

Shernoff, D. J. (2013), Optimal Learning Environment to Promote Student Engagement. New York: Springer.

Shernoff, D.J. (2010), Engagement in After-School Programs as a Predictor of Social Competence and Academic Performance', American Journal of Community Psychology, 45:3-4, pp. 325-337. http://dx.doi.org.libproxy.helsinki.fi/10.1007/s10464-010-9314-0. Accessed 10 May 2017.

Shernoff, D. J, Csikszentmihalyi, M., Scneider, B. and Shernoff, E. S. (2003), 'Student Engagement in High School Classrooms from the Perspective of Flow Theory', School Psychology 
Quarterly, 18:2, pp. 158-176. http://ovidsp.uk.ovid.com.libproxy.helsinki.fi. Accessed 10 May 2017.

Shusterman, R. (2013), 'Body and the Arts: The Need for Somaesthetics', Diogenes, 59:1-2, 720.

Spendlove, D. (2007), 'A Conceptualisation of Emotion within Art and Design Education', International Journal of Art \& Design Education, 26:2, pp. 155-166.

Spillers, F. (2004), 'Emotion as a cognitive artifact and the design implications for product that are perceived as pleasurable', Experience Dynamics, pp. 1-14.

The National Core Curricula for the Basic Education in the Arts, (2002), Finnish National Board of Education, http://www.oph.fi/download/123026_visuaal_tait_ops_2002.pdf. Accessed 17 February 2017.

The National Core Curriculum for Basic Education in the Arts (2017). Finnish Ministry of Education and Culture.

http://oph.fi/saadokset_ja_ohjeet/opetussuunnitelmien_ja_tutkintojen_perusteet/taiteen_p erusopetus. Accessed 25 January 2018.

Tsakiris, M., Schutz-Bosbach, S. and Callagher, S. (2007), 'On agency and body ownership: Phenomenological and neurocognitive reflections', Consciousness and Cognition, 16:3, pp. 661-666.

Tuomi, J. and Sarajärvi, A. (2002), Laadullinen tutkimus ja sisällönanalyysi, Helsinki: Tammi.

Vogeley, K. and Fink, G.R. (2003), 'Neural correlates of the first-person-perspective', Trends in Cognitive Sciences, 7:1, pp. 38-42.

\section{Biographys}

\section{Milla Ojala}

M.A. (Education), Ph.D student, Teacher Education, University of Helsinki, Finland

She currently works as a craft-art teacher at the Visual Arts School Aimo in Hämeenlinna, Finland.

She studies educational science in preparation for a Ph.D at the Department of Teacher Education, University of Helsinki. Her research interests concern perceptual processes and emotional experiences in craft process and craft pedagogy.

Contact: Visual Arts School Aimo, P.O. Box 1000 (Keinusaarentie 1), 13101, Hämeenlinna, Finland

E-mail: milla.ojala@hameenlinna.fi

\section{Seija Karppinen}

Ph.D (Education), Senior Lecturer, Teacher Education, University of Helsinki, Finland

She has worked as a teacher in crafts in basic education and as a lecturer for more than twenty years in teacher education at the University of Helsinki (in crafts science, early childhood education, primary teacher education, and adult education). She also provides tuition for in-service education and supervises doctoral candidates. Her current focus in teaching and research is on interdisciplinary approaches, the use of new technology, and innovation pedagogy, storytelling and improvisation in crafts, craft art, smart textiles, making culture, and how all these could be brought into schools.

Contact: Department of Educational Sciences, University of Helsinki, P.O. Box 8

(Siltavuorenpenger 10), FIN-00014, Finland.

E-mail: seija.karppinen@helsinki.fi 


\section{Erja Syrjäläinen}

$\mathrm{Ph} . \mathrm{D}$, professor of craft education at the University of Helsinki, in the Faculty of Educational Sciences. She has worked in the craft teacher education for over two decades. Her research interests focus on teachers' pedagogical thinking, learning craft skills and mentoring teaching practice. The pedagogy of teaching, learning and evaluating crafts are at the centre of her interests.

Contact: Department of Educational Sciences, University of Helsinki, P.O. Box 8 (Siltavuorenpenger 10), FIN-00014, Finland.

E-mail: erja.syrjalainen@helsinki.fi

\section{List of illustration}

Figure 1: In Lahti, students designed and manufactured their own clothing line. Photo by Milla Ojala

Figure 2: In Valkeakoski, students implemented their individual projects in wood and fabric. Photo by Milla Ojala

Figure 3: Emotional experiences during craft-art process

Figure 4: Three subcategories of emotional experiences, properties and dimensions according to GT procedures of axial coding (Corbin and Strauss 2015: 61; Saldana 2013: 218)

Figure 5: The categories and subcategories found in the analysis

Figure 6: The relation between categories found in the analysis and the conceptual framework of the study 


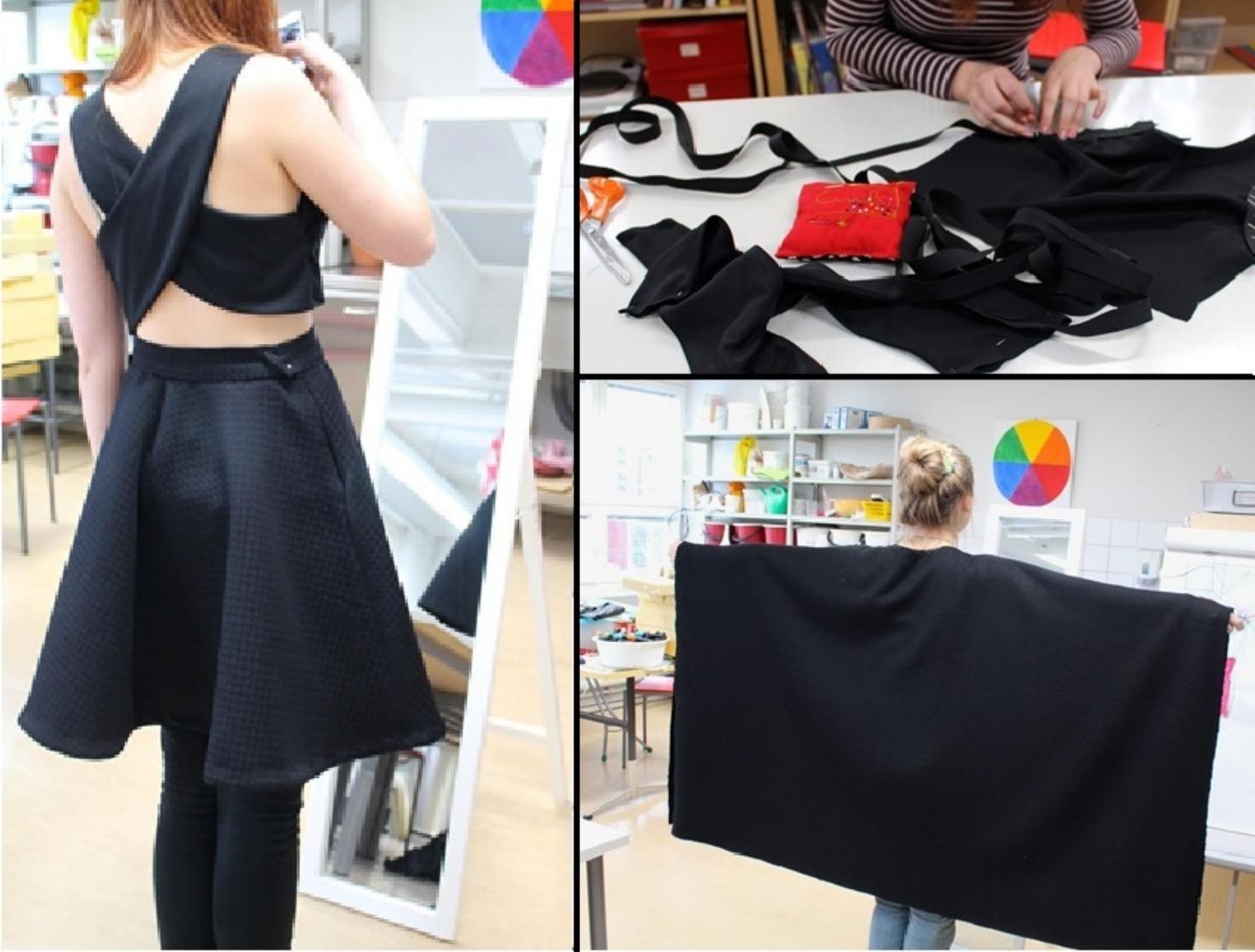




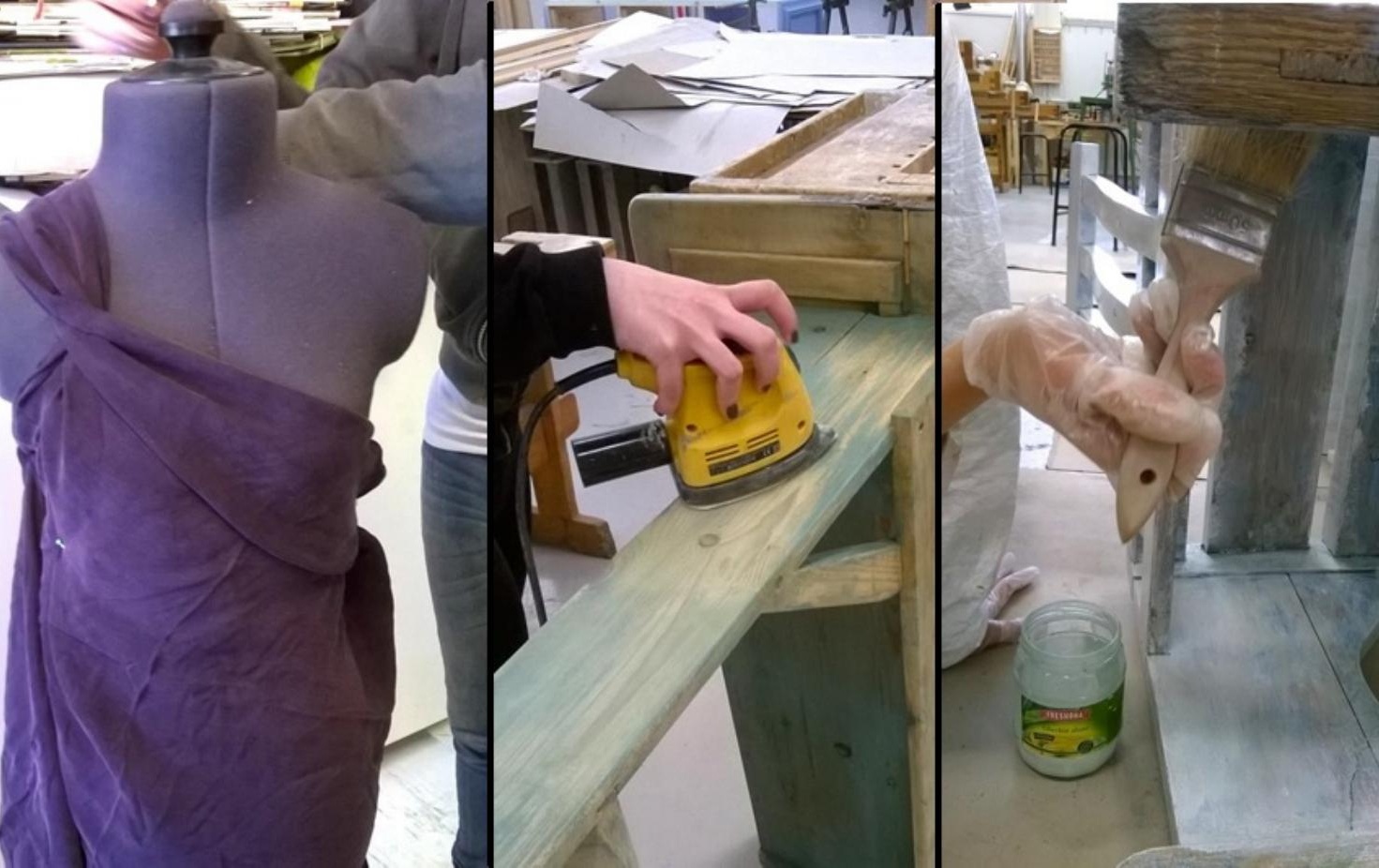




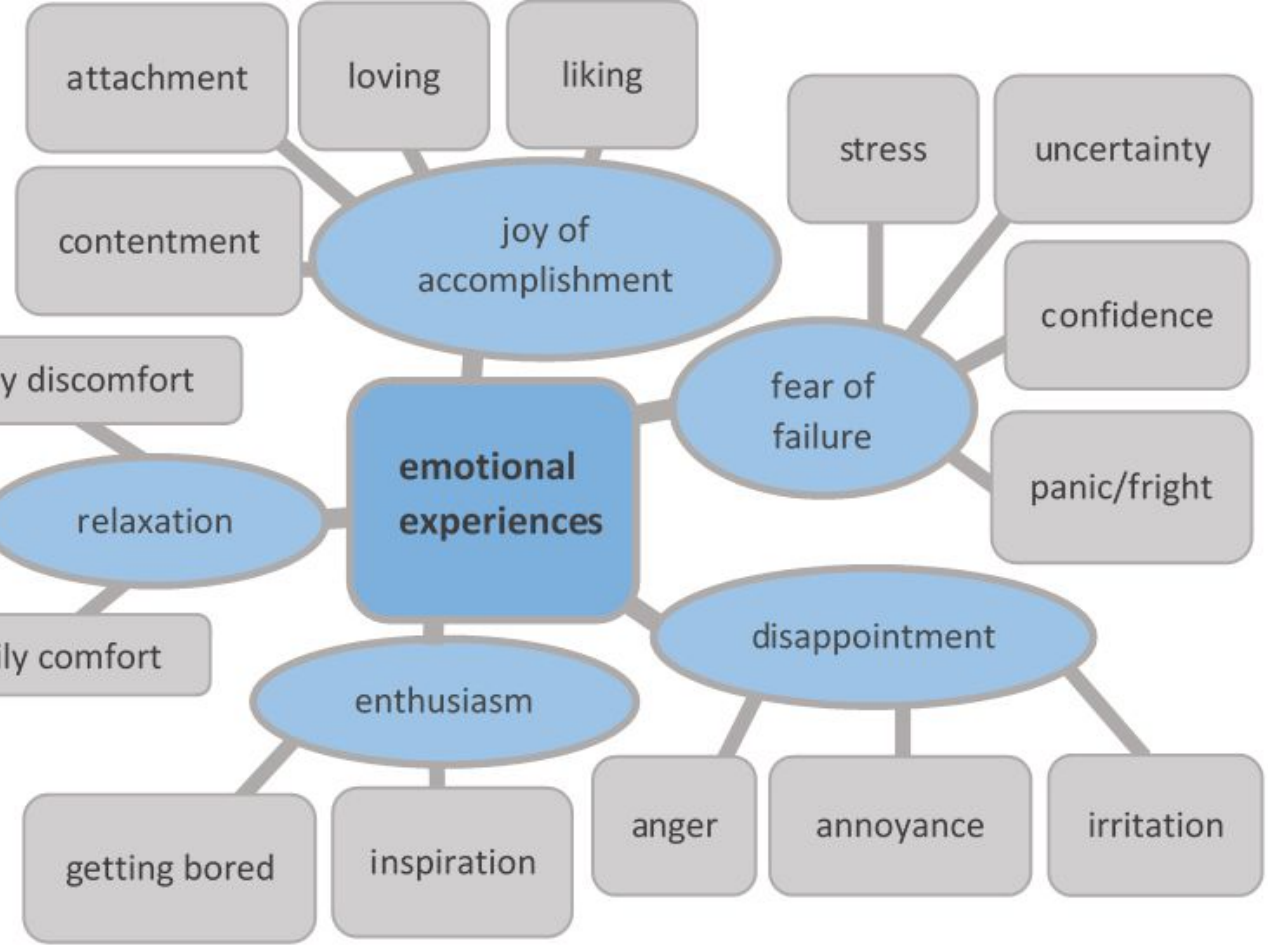




\section{MANAGEMENT OF THE PROCESS}

\section{obstructive--_-_- ENERGY OF EMOTION --_-_--conducive}

discouraging

DYNAMICS OF EMOTION

encouraging

\section{MAKER'S OWN AESTHETICS}

rejection ---

EVALUATION OF AN OUTCOME appreciation

MAKER'S PRESENCE 


\section{maker's \\ presence}

\section{making}

\section{sense of}

self in

EMOTIONAL

\section{craft-art}

artefactcentred

\section{EXPERIENCES}

\section{ENGAGEMENT}

\section{management of the process}

\section{maker's own aesthetics}

\section{maker-centred}

process-centred 
interest

concentration

meaningful product

meaningful

\section{ENGAGEMENT}

flow-optimal

experience

\section{somatic}

experience

making

sense of

self in

emotional ownership

craft-art

\section{EMOTIONAL}

\section{EXPERIENCES maker's presence}

process-centred

maker-centred 